\title{
TAVOITTEELLISTA KUNTOUTUSTA JA KUNTOUTUMISTA
}

\section{PÄÄKIRJOITUS}

RIITTA

SEPPÄNEN-JÄRVELÄ
Vuoden 2020 ensimmäinen Kuntoutus-lehti on teemanumero, joka syventyy kuntoutuksen ja kuntoutumisen tavoitteellisuuteen, erityisesti GAS-menetelmän (Goal Attainment Scaling) soveltamiseen Kelan kuntoutuksessa. Menetelmän käyttämisestä on saatu runsaasti uutta tietoa Muutos-hankkeen tutkimuksissa (2015-2019), joissa selvitettiin Kelan kuntoutuksen muutosten vaikutuksia asiakkaille. Tutkimukset kohdistuivat useiden eri kuntoutuspalveluiden toteutumiseen sekä siihen, miten hyvän kuntoutuskäytännön mukaista GAS-menetelmää sovelletaan kuntoutujan omien tavoitteiden määrittelyssä ja arvioinnissa Kelan kuntoutuksessa.

GAS-menetelmässä määritetään kuntoutujan tavoitteet, ja tavoitteiden toteutumista voidaan tarkastella yksilö- tai ryhmätasolla tilastollisilla menetelmillä. Kun arviointimenetelmä Amerikassa 1960-luvulla kehitettiin, keskeinen intressi oli luoda käsitteistö ja metodi, joita mielenterveyskuntoutusta tuottavat yksiköt saataisiin käyttämään. Tavoitteena oli kerätä yhdenmukaista ja vertailtavaa tietoa, jota oli mahdollista hyödyntää myös tarvittavien henkilöstöresurssien arvioimisessa. Nykyään GAS-menetelmää käytetään laajasti niin yksittäisen kuntoutujan tavoitteiden määrittämiseen ja niiden saavuttamisen arviointiin kuin kuntoutuspalveluiden vaikutusten ja tuloksellisuuden arviointiin.

Kelan kuntoutuksessa GAS-menetelmää on käytetty jo lähes vuosikymmen kuntoutuksen tavoitteiden laatimisen ja arvioinnin välineenä. Menetelmän käyttöönotto eri kuntoutusmuodoissa on edennyt vähitellen ja vaiheittain alkaen ammatillisesta kuntoutuksesta. Lisäksi se on osa Kelan kuntoutuksen tuloksellisuuden seurantaa. GAS-menetelmän soveltamista Kelan kuntoutuksessa seurattiin varsin paljon erityisesti käyttöönoton alkuvaiheessa: Esimerkiksi Hilkka Ylisassin (2012) tutkimuksessa tarkasteltiin GAS:in soveltamista ammatillisten tavoitteiden asettamisessa. Seija Sukulan (2013) tutkimuksessa selvitettiin, miten kuntoutuksen kannalta merkitykselliset tavoitteet tulivat GAS-menetelmän käyttämisessä esille ja kuinka tavoitteet toteutuivat. Minna Ylilahti (2013) tarkasteli tavoitteita kuntoutujan kokemuksellisesta näkökulmasta, ja Aila Pikkarainen kollegoineen (2013) selvitti IKKU-kuntoutuksessa GAS-menetelmän soveltamista ikääntyneille kuntoutujille. Menetelmän toimivuutta selvitettiin niin ikään kuntoutuksen kehittämishankeympäristössä, kuten MS-kuntoutuksessa (Salminen ym. 2014). 
Näissä aiemmissa tutkimuksissa GAS-menetelmän soveltamisen haasteina on tullut esille kuntoutuksen ajallinen ja prosessimainen eteneminen sekä muutokset kuntoutujien työ- ja toimintakyvyssä ja motivaatiossa. Varsinkin menetelmän käyttöönoton alkuvaiheissa tuli esille kuntoutuksen toteuttajien tottumattomuus tavoitteiden määrittelyyn ja niiden saavuttamisen arviointiin niin asiakkaiden kuin kuntoutuksen toteuttajien osalta. Haasteena on myös ollut moniammatillisuuden hyödyntäminen tavoitteiden asettamisessa.

Kuntoutuksen taustalla on ajattelu, jonka mukaan tavoitteet perustuvat henkilön kuntoutustarpeisiin (Karhula ym. 2016). Toisaalta kun kuntoutujien kuntoutustarpeita ja GAS-tavoitteita tarkasteltiin kuntoutujan asiakirjojen valossa, havaittiin, etteivät kuntoutustarpeet automaattisesti muotoudu tavoitteiksi, eivätkä asetetut tavoitteet aina vastaa tarpeisiin (Seppänen-Järvelä ym. 2015). Tavoitteet ja keinot voivat myös sekoittua. On myös havaittu, että usein henkilökohtaiseksi tavoitteeksi kirjataan fyysiseen terveydentilaan liittyviä tavoitteita, vaikka kuntoutujan tarpeet olisivat henkisen jaksamisen tai psyykkisen terveyden tukemisessa. Fyysiset vaivat voivat olla selkeämmin muotoiltavissa tavoitteiksi kuin moninaiset elämänhallinnan ongelmat ja itsensä kehittämiseen liittyvät asiat.

Näissä aiemmissa tutkimuksissa on myös huomattu, että tavoitteita on kirjattu hyvin eritasoisesti siltä osin, kuinka helposti tavoitteet ovat saavutettavissa kuntoutuksen aikana. Tavoitelomakkeeseen kirjataan useimmiten kuntoutumisen kannalta keskeisiä tavoitteita, mutta joskus merkittäviäkin tavoitteita voi jäädä kirjaamatta eri syistä. Toisaalta on myös havaittu, että kuntoutuja pystyi itse päättämään, minkä verran ja mitä asioita ja tarpeita hän halusi tuoda esille tavoitteiden asettamiseen. Esimerkiksi oma tai läheisen päihdeongelma, pulmat parisuhteessa tai muut ihmissuhdeongelmat olivat asioita, joita jotkut kuntoutujat eivät välttämättä halunneet tuoda käsiteltäviksi. GAS-menetelmä on lähtökohdaltaan aina asiakaslähtöinen; on kuitenkin havaittavissa, että osalle kuntoutujista tavoitteellinen toiminta ja tavoitteiden määrittely ovat luontevampaa ja helpompaa kuin toisille.

Aiemmat tutkimukset ovat tuoneet esille, että GAS-menetelmä on osoittautunut rajoituksistaan huolimatta Kelan kuntoutuksessa toimivaksi menetelmäksi. Henkilökohtaiset GAS-tavoitteet ikään kuin havainnollistavat ennen kaikkea kuntoutuksen, ei niinkään kuntoutumisen, tavoitteita. Kuntoutuksen tavoitteellisuus sinänsä edistää kuntoutumista, mutta kuntoutumisen vaikutuksia ja vaikuttavuutta ei voida arvioida ainoastaan GAS-tavoitteiden saavuttamisen kautta.

Arviointitutkimuksen piirissä on jo 1970-luvulta alkaen keskusteltu tavoitelähtöisen arvioinnin pulmista (ks. esim. Scriven 1991). Eräs olennainen haaste tavoitelähtöisessä arvioinnissa on niin sanottu 'tunnelinäkö', joka estää havaitsemaan sellaisia tärkeitä tuloksia ja vaikutuksia, joita ei ole tavoitteisiin määritelty tai joita ei ole vielä tavoitteita asetettaessa osattu odottaa. Mitä muuttuvammassa ja epävakaammassa ympäristössä toimitaan, sitä ongelmallisempaa on tavoitteiden käyttäminen arvioinnin mittapuina, koska tavoitteiden 
mitattavuus ja täsmällisyys vaihtelevat toiminnan aikana. Toinen ongelma koskee itse tavoitteiden asettamista. Tavoitteet itsessään saattavat olla epämääräisiä tai epärealistisia toteuttaa annetussa ajassa ja resursseilla. Tällöin hyväkin toiminta saattaa tavoitteiden saavuttamisen valossa näyttää vaatimattomalta. Kuulostaako tutulta myös kuntoutuspalveluiden näkökulmasta?

GAS-menetelmän käyttöä Kelan kuntoutuksessa on seurattu ja tutkittu suhteellisen paljon. Viime aikaisissa Kelan kuntoutuspalveluiden toteutumista koskeneissa tutkimuksissa tavoitteisiin liittyvät tutkimuskysymykset ovat olleet vahvasti esillä. Näiden kysymysten kautta on tuotettu tietoa GAS-menetelmän soveltamisesta. Kiinnostus on kohdistunut esimerkiksi siihen, kuinka ja millaisia tavoitteita on asetettu, kuinka tavoitteita on seurattu ja arvioitu sekä kuinka kuntoutujan toimijuutta on tuettu. Kun tiedetään, että kuntoutuksen tavoitteiden tulisi olla kuntoutujan tilanteen mukaan muuttuvia, on tärkeätä tuottaa tutkimuksella tietoa siitä, kuinka kuntoutuksen ammatilliset käytännöt näissä toteutuvat.

Tämän teemanumeron kirjoittajakunta koostuu Muutos-hankkeen eri osatutkimusten tutkijoista. Maarit Karhulan ja Tuija Heiskasen tieteellisessä artikkelissa kuvataan, millaisia tavoitteita Kelan Tules-kuntoutuksessa on, miten tavoitteet ohjaavat kuntoutusta ja kuntoutumista sekä miten hyvin tavoitteet saavutettiin kuntoutuksen aikana. He havaitsivat, että kuntoutujien omien tavoitteiden tulisi kuitenkin olla nykyistä paremmin läsnä koko kuntoutusprosessin ajan, vaikka tavoitteet ja GAS-työskentely sinänsä koetaan tärkeäksi. Toisessa tieteellisessä artikkelissa tutkijaryhmä Sinikka Hiekkala, Lotta Hautamäki, Mirkka Vuorento, Asta Tuomenoksa ja Erja Poutiainen analysoivat aivoverenkiertohäiriön sairastaneiden kuntoutuskursseille osallistuneiden kuntoutujien tavoitteita ICF-luokituksen näkökulmasta. Tavoitteiden siltaus ICF-luokitukseen on tehokas keino tehdä näkyväksi se, millä toimintakyvyn osa-alueella kuntoutujan kanssa työskennellään, ja samalla tarkastella kuntoutumisprosessin kokonaisuutta.

Nea Vänskä, Salla Sipari ja Krista Lehtonen raportoivat Kuntoutujan omat tavoitteet -tutkimuksesta, jossa erityinen huomio kiinnittyi lapsille ja heidän perheilleen tarkoitettuun sekä ajallisesti lyhytkestoiseen kuntoutukseen. Tutkimuksen aineisto kerättiin Kelan järjestämiltä sopeutumisvalmennuskursseilta. Tutkimuksessa havaittiin, että ammattilaiset, läheiset ja kuntoutujat kuvasivat runsaasti kuntoutuksesta saatuja odottamattomia hyötyjä, kuten muutoksia ajattelu- ja toimintatavoissa tai uusia voimavaroja ja verkostoja arjessa pärjäämiseksi. Nämä eivät kuitenkaan välttämättä näkyneet asetettujen tavoitteiden saavuttamisena. Lehden toisessa katsauksessa Johanna Korkeamäki, Jaakko Harkko, Erja Poutiainen ja Liisa Vaalasranta tarkastelevat tavoitteiden asettamista ja niiden toteutumista nuorten mielenterveyskuntoutuksessa. He keskustelevat tavoitteiden ja vaikutusten arvioimisen haasteellisuudesta: arvioinnissa usein käytetyt mielenterveysoireita kartoittavat mittarit eivät välttämättä kuvaa riittävän osuvasti nuorten elämässä tapahtunutta muutosta. Tutkimuksessa, jossa arvioitiin OPI-kuntoutuskurssien to- 
teutumista, palveluntuottajat korostivat, että kuntoutujan tavoitteista tulee mahdollisimman omakohtaisia ja sitouttavia, kun nuoret sanottavat ja tuottavat omat tavoitteensa oman henkilökohtaisen prosessointinsa tuloksena.

Antoisia lukuhetkiä ja terveyttä tänä poikkeuksellisena keväänä, jota pandemia varjostaa.

\author{
Riitta Seppänen-Järvelä \\ Kuntoutus-lehden päätoimittaja
}

\title{
Kirjallisuus
}

Karhula M, Veijola A, Ylisassi H (2016) Tavoitteiden asettamisen käytäntö. Teoksessa I Autti-Rämö, A-L Salminen, M Rajavaara, A Ylinen (toim.) Kuntoutuminen. Duodecim, Helsinki, 225-238.

Pikkarainen A, Vaara M, Salmelainen U (toim.) (2013) Gerontologisen kuntoutuksen toteutus, vaikuttavuus ja tiedon välittyminen. Ikääntyneiden kuntoutujien yhteistoiminnallisen kuntoutuksen tutkimus- ja kehittämishankkeen loppuraportti. Kela, Helsinki.

Salminen A-L, Hämäläinen P, Karhula M, Kanelisto K, Ruutiainen J (2014) MS-kuntoutujien ryhmämuotoinen moniammatillinen avokuntoutus. Kuntoutusmallin kehittäminen ja arviointi. Sosiaali- ja terveysturvan tutkimuksia 129, Kela, Helsinki.

Scriven M (1991) Evaluation Thesaurus (4th ed.). SAGE Publications, Newbury Park. Seppänen-Järvelä R, Syrjä V, Juvonen-Posti P, Pesonen S, Laaksonen M, Tuusa M, Savinainen M, Henriksson M (2015) Yhteistoimintaa ja yksilöllisiä valintoja kuntoutumisen polulla. Kelan työhönkuntoutuksen kehittämishankkeen tapaustutkimus. Sosiaali- ja terveysturvan tutkimuksia 141, Kela, Helsinki.

Sukula S (2013) Hyvin laaditut tavoitteet ovat kuntoutuksen selkäranka. Kuntoutus 2, 41-47.

Ylilahti M (2013) Itsestä kiinni. Etnografinen tutkimus työikäisten laitoskuntoutuksesta. Jyväskylä studies in education, psychology and social research 469. Jyväskylän yliopisto, Jyväskylä.

Ylisassi H (2012) GAS-menetelmän (Goal Attainment Scaling) käyttö ammatillisessa (työhön liittyvässä) kuntoutuksessa. Tutkimus- ja kehittämishanke Aslak-kuntoutuksessa. Hankkeen jatko-osa 2011-2012. Hankeraportti 29.3.2012. Verve Consulting. Saatavissa: <http://www.kela.fi/documents/10180/12149/gas_kokeiluhanke_jatkoraportti_hy_29.3.pdf>. 